\title{
The Transmembrane Protein Semaphorin 6A Repels Embryonic Sympathetic Axons
}

\author{
Xiao-Mei Xu, ${ }^{1}$ Daniel A. Fisher, ${ }^{2,3}$ Lijuan Zhou, ${ }^{2}$ Fletcher A. White, ${ }^{2}$ Sheldon $\mathbf{N g},{ }^{1}$ William D. Snider, ${ }^{2,3}$ and \\ Yuling Luo ${ }^{1}$ \\ ${ }^{1}$ Exelixis Pharmaceuticals, Inc., South San Francisco, California 94080, 2 Department of Neurology, Center for the Study of \\ Nervous System Injury, Washington University School of Medicine, St. Louis, Missouri 63110, and ${ }^{3}$ Neuroscience Center, \\ University of North Carolina School of Medicine, Chapel Hill, North Carolina 27599
}

Semaphorin 6A (Sema6A) (previously named Semaphorin Vla) is the originally described member of the vertebrate semaphorin class 6 , a group of transmembrane semaphorins homologous to the insect semaphorin class 1. Although Sema-1a (previously named semaphorin I) has been implicated in axon guidance in insects, the function of Sema6A is currently unknown. We have expressed the extracellular domain of Sema6A in mammalian cells as either a monomeric or a dimeric fusion protein and tested for potential axon guidance effects on two populations of embryonic neurons in growth cone collapse and collagen matrix chemorepulsion assays. Sema6A was observed to induce growth cone collapse of sympathetic neurons with an EC50 of $\sim 200$ pM, although a 10-fold higher (EC50 of $\sim 2 \mathrm{~nm}$ ) concentration was necessary to induce growth cone collapse of dorsal root ganglion neurons. The activity of Sema6A is likely to depend on protein dimerization or oligomerization. Although Sema6A mRNA is expressed in complex patterns during embryonic development, it is strikingly absent from sympathetic ganglia. Sema6A is, however, expressed in areas avoided by sympathetic axons and in areas innervated by sympathetics, but before their arrival. Our results demonstrate that transmembrane semaphorins, like the secreted ones, can act as repulsive axon guidance cues. Our findings are consistent with a role for Sema6A in channeling sympathetic axons into the sympathetic chains and controlling the temporal sequence of sympathetic target innervation.

Key words: semaphorin; growth cone collapse; repulsion; sympathetic development; plexin; axon guidance
Developing axons are guided toward their target tissues by means of their growth cones at the axon tips, which recognize and respond to both attractive and repulsive guidance cues in the environment along the axonal pathways (for review, see TessierLavigne and Goodman, 1996). Semaphorins are a large family, including both secreted and membrane associated proteins, many of which have been implicated as inhibitors or chemorepellents in axon pathfinding, fasciculation and branching, and target selection (for review, see Mark et al., 1997). All semaphorins possess an extracellular semaphorin (Sema) domain of $\sim 500$ amino acids at the $\mathrm{N}$ terminus. Additional sequence motifs $\mathrm{C}$ terminal to the semaphorin domain allow the semaphorins to be classified into eight distinct subfamilies (Adams et al., 1996; Xu et al., 1998; Semaphorin Nomenclature Committee, 1999; Yu and Kolodkin, 1999).

SEMA3A (collapsin-1-Sema III/D) is a member of class 3 vertebrate secreted semaphorins (Kolodkin et al., 1993; Luo et

\footnotetext{
Received July 6, 1999; revised Jan. 21, 2000; accepted Jan. 24, 2000.

This research was supported by Exelixis Pharmaceuticals and National Institutes of Health Grant P01-NS34448 to W.D.S. We thank Corey Goodman, Marc Tessier-

Lavigne, and our colleagues at Exelixis for their encouragement and support, and Agnes Eliares for expert technical assistance.

Drs. Xu and Fisher contributed equally to this work.

Correspondence should be addressed to Yuling Luo, Exelixis Pharmaceuticals, Inc., 260 Littlefield Avenue, South San Francisco, CA 94080. E-mail: yluo@exelixis. com.

Dr. Fisher's and Dr. Snider's present address: Neuroscience Center, University of North Carolina School of Medicine, Chapel Hill, NC 27599.

Dr. White's present address: Department of Neurology, Neuroscience Research Center, Yale University School of Medicine, Veterans Affairs Medical Center, West Haven, CT 06516.

Copyright (C) 2000 Society for Neuroscience $\quad 0270-6474 / 00 / 202638-11 \$ 15.00 / 0$
}

al., 1993, 1995; Puschel et al., 1995). It is the best characterized chemorepellent molecule in the semaphorin family and has been implicated in the guidance of developing axons of the peripheral nervous system and CNS. SEMA3A can induce the collapse of sensory and sympathetic growth cones and can repel sensory and sympathetic axons from a distance (Luo et al., 1993; Messersmith et al., 1995; Puschel et al., 1995; Adams et al., 1997; Feiner et al., 1997; Kobayashi et al., 1997; Koppel et al., 1997; Shepherd et al., 1997; Chen et al., 1998; Takahashi et al., 1998). Targeted deletion of Sema3A in mice resulted in defects in the patterning of sensory and motor axon projections (Behar et al., 1996; Taniguchi et al., 1997). Neuropilins have been shown to function as receptors or components of receptor complexes for class 3 secreted semaphorins (Chen et al., 1997; He and Tessier-Lavigne, 1997; Kolodkin et al., 1998). In particular, neuropilin-1 was shown to be a receptor for Sema3A. Mice lacking neuropilin-1 exhibit phenotypes similar to mice lacking Sema3A (Kitsukawa et al., 1997). Although SEMA3A was shown to exhibit strong repulsive activity toward sympathetic neurons, the structure of the sympathetic ganglion chains in Sema3A null mice is only mildly defasciculated (Taniguchi et al., 1997). Many of the class 3 secreted semaphorins are known to be repulsive toward sympathetic neurons (Adams et al., 1997; Feiner et al., 1997; Chen et al., 1998; Giger et al., 1998; Takahashi et al., 1998). It is possible that developing sympathetic axons may be exposed to a number of semaphorins with redundant inhibitory activity.

Although many members of class 3 secreted semaphorins have been shown to be chemorepulsive toward selected populations of embryonic neurons, it is not yet known whether vertebrate trans- 
membrane semaphorins function in a similar manner. In insects, grasshopper Sema-1a (Semaphorin I), a transmembrane semaphorin with no obvious structural motifs following the Sema domain (or Sema-PSI domain, as defined by Bork et al., 1999), has been implicated in axon guidance. In vivo antibody blocking experiments show that the G-Sema-1a is involved in the ventral turn of Ti1 pioneer axons in the developing grasshopper limb bud (Kolodkin et al., 1992). Recent experiments suggest that G-Sema-1a could function as an attractive cue for the growth cones of the subgenual organ (Wong et al., 1997). Drosophila Sema-1a is closely related to G-Sema-1a. Genetic analysis suggests that D-Sema-1a could function as a repulsive guidance cue for embryonic motor axons (Yu et al., 1998). The repulsive function of D-Sema-1a is likely to be mediated by its receptor Drosophila Plexin A, which was shown to interact with D-Sema-1a both genetically and biochemically (Winberg et al., 1998).

Sema6A is the first described member of class 6 vertebrate transmembrane semaphorins that shares the same arrangement of structural domains as found in the insect Sema-1a (Zhou et al., 1997). The expression of Sema6A mRNA during embryonic stages is regulated spatially and temporally in regions important to nervous system development (Zhou et al., 1997). Since the discovery of Sema6A, several other members of this class have also been identified, yet the function of these semaphorins remains primarily unknown (Eckhardt et al., 1997; Kikuchi et al., 1997, 1999; L. Zhou, D. A. Fisher, F. A. White, and W. D. Snider, unpublished results). Here, we show Sema6A to be an inhibitory molecule active on embryonic sympathetic and sensory axons in vitro and describe an expression pattern of this molecule consistent with a role as a local inhibitor of developing sympathetic axons in vivo.

\section{MATERIALS AND METHODS}

Expression constructs. Constructs for Sema6A protein expression in mammalian cells were made as described previously (Xu et al., 1998). Briefly, the extracellular domain of Sema6A cDNA was subcloned into Myc-His-tagged and Fc-tagged expression vectors to create the constructs allowing the expression of $\mathrm{C}$ terminally tagged Myc-His or Fc fusion proteins, Sema6A-mh and Sema6A-Fc, respectively. SEMA3A-Fc and SEMA7A-Fc (previously named sema $\mathrm{K} 1-\mathrm{Fc}$ ) expression constructs were made and described previously (Xu et al., 1998).

Expression and purification of Sema6A fusion proteins. Stable 293EBNA cell lines secreting Myc-His-tagged or Fc-tagged Sema6A extracellular domain were derived from transient transfection of the above expression plasmids, followed by selection with G418. Conditioned media from stably transfected cell lines were collected, and the protein production and integrity were confirmed by Western blot using anti-Myc and anti-Fc antibodies. The dimerization of the fusion proteins was assessed by running samples in SDS-PAGE gel under reducing (sample buffer with $10 \%$ 2-mercaptoethanol) or nonreducing (sample buffer without 2-mercaptoethanol) conditions. For the purification of Sema6Aa-mh, conditioned media from the Sema6A-mh-expressing cell line were collected, and buffer was exchanged into Ni-NTA binding buffer ( $20 \mathrm{~mm}$ Tris, $\mathrm{pH} 7.5$, $100 \mathrm{~mm} \mathrm{NaCl}, 0.1 \%$ cholic acid, and $30 \mathrm{~mm}$ imidazole, $\mathrm{pH}$ 7.0). The protein was bound to nickel Ni-NTA resin (Qiagen, Hilden, Germany) and eluted with imidazole ( $150 \mathrm{~mm}$ in $20 \mathrm{~mm}$ Tris, pH 7.5, $100 \mathrm{~mm} \mathrm{NaCl}$, and 1 mM EDTA, pH 5.0). For the purification of Sema6A-Fc, conditioned media from the Sema6A-Fc-expressing cell line were collected, and buffer was exchanged into Protein A Sepharose binding buffer (20 $\mathrm{mm}$ NaPO4, $\mathrm{pH}$ 7.0). The protein was bound to Protein A Sepharose CL-4B resin (Amersham Pharmacia Biotech, Piscataway, NJ) and eluted with $40 \mathrm{~mm} \mathrm{NaCitrate}$ and $20 \mathrm{~mm} \mathrm{NaCl}, \mathrm{pH} 3.2$. The protein concentrations of Sema6A-mh and Sema6A-Fc were estimated by comparing the intensity of Coomassie blue stain in SDS-PAGE gel using BSA as standard.

Growth cone collapse assay. Semaphorin fusion proteins were assayed for growth cone collapsing activity on explanted chick embryonic day 7
(E7) dorsal root ganglia and E8 sympathetic chain ganglia as described previously (Luo et al., 1993). Briefly, explants were dissected from chick embryos and incubated in F12-based defined medium supplemented with bovine pituitary extract and nerve growth factor (NGF) on eight-well chamber slides precoated with poly-ornithine and mouse laminin. The following day, purified semaphorin proteins, as described above, were added to the explanted culture. After $1 \mathrm{hr}$ incubation, the explants were fixed in $4 \%$ paraformaldehyde at room temperature for $30 \mathrm{~min}$. Explants were then washed in PBS and stained with $3 \mathrm{U} / \mathrm{ml}$ rhodamine phalloidin (Molecular Probes, Eugene, OR) in PBS at room temperature for $2 \mathrm{hr}$. For mouse dorsal root ganglion (DRG) explants in which a significant outgrowth of non-neuronal cells was present, axons were stained with a monoclonal antibody to growth-associated protein 43 (GAP-43) $(2 \mu \mathrm{g} / \mathrm{ml}$; Boehringer Mannheim, Indianapolis, IN). Growth cones were visualized under fluorescence microscope $(40 \times)$ and scored as being either normal or collapsed. The percentage of collapsed growth cones was then plotted against the concentration of purified protein added to the cultured explant. For experiments using mice, dorsal root or sympathetic ganglia were dissected from E15 mouse embryos, and explants were cultured as for chick.

Partially purified SEMA3A produced from baculovirus expression system was used as a positive control in the dose-response study of Sema6A-Fc activity. Human SEMA3A was engineered into the baculovirus transfer vector, pAcMP2 (PharMingen, San Diego, CA), and the recombinant baculovirus capable of directing the expression of recombinant SEMA3A was produced. After $48 \mathrm{hr}$ after infection, SEMA3A protein was highly expressed in the culture media of Hi5 cells at $2-5 \mathrm{mg} / 1$ culture. The protein was enriched on an S-Sepharose cation exchange column and was further purified through a Heparin-Sepharose column to a purity of above $50 \%$.

Chemorepulsion assay. Chemorepulsion assays were performed following the work of Messersmith et al. (1995). Embryonic day 8 sympathetic ganglia and embryonic day 7 dorsal root ganglia were dissected from chick embryos. The explants were cocultured with aggregates of COS-7 cells secreting Sema6A-Fc, Sema6A-mh, SEMA3A-Fc, SEMA7A-Fc, and mock $\mathrm{Fc}$ into the collagen bed. The cocultures were incubated at $37^{\circ} \mathrm{C}$ for $3 \mathrm{~d}$ in $\mathrm{F} 12$-based defined medium supplemented with bovine pituitary extract and nerve growth factor (Luo et al., 1993) and were then fixed and visualized by phase contrast on an inverted microscope. The amounts of neurite outgrowth from sympathetics or DRGs in the proximal and distal quadrants in relation to the COS cell aggregates were compared and recorded. Positive chemorepulsive activity was scored when the axons of the explants were not present in the proximal quadrants. The expression of semaphorins was confirmed by Western blot.

In situ hybridization. Embryos were obtained from time pregnant CF1 mice (Charles River Laboratories, Wilmington, MA). The plug date was considered embryonic day 0 . Pregnant females were killed by overdose of sodium pentobarbital anesthesia, and embryos were extracted by cesarean section and quickly frozen on dry ice in OCT embedding compound (Tissue-Tek, Sakura). Cryostat sections $(18-20 \mu \mathrm{M})$ were cut in horizontal sections, thaw-mounted onto SuperFrost Plus slides (Fisher Scientific, Houston, TX), and stored at $-20^{\circ} \mathrm{C}$. Slides with cryostat sections were fixed, washed, acetylated, and dehydrated according to the protocol described by Wright et al. (1995).

In situ hybridization was performed with plasmid SD89, containing a $340 \mathrm{bp}$ fragment of Sema6A cDNA internal to the semaphorin domain (Zhou et al., 1997). Plasmid SD89 was linearized to generate sense and antisense probes with XhoI and NotI, respectively. Probes were generated by in vitro transcription with T7 (antisense) and T3 (sense) RNA polymerases, in the presence of ${ }^{33} \mathrm{P}-\mathrm{UTP}$ (DuPont-NEN, Boston, MA). Sections were hybridized with radiolabeled probe $\left(10^{6} \mathrm{cpm}\right)$ overnight at $55^{\circ} \mathrm{C}$ in hybridization mixture as described previously (Wright et al., 1995). On the following day, slides were washed with $4 \times$ SSC and treated with RNase A (40 $\mu \mathrm{g} / \mathrm{ml}$; Boehringer Mannheim), rinsed with serial dilutions of SSC, and dehydrated as described previously (Wright et al., 1995). Sections were exposed to Kodak NTB-2 photographic emulsion (Eastman Kodak, Rochester, NY) for $10 \mathrm{~d}$. Slides were developed and counterstained with hematoxylin and eosin as described previously (Wright et al., 1995). Sections were viewed and photographed under dark field with a Nikon (Tokyo, Japan) Eclipse microscope. Slide photographs were scanned using Polaroid SprintScan 35 connected to Macintosh PC 9600 (Apple Computers, Cupertino, CA). Figures were generated with brightness-contrast adjustments using Adobe Photoshop 5.0 software (Adobe Systems, Mountain View, CA). 


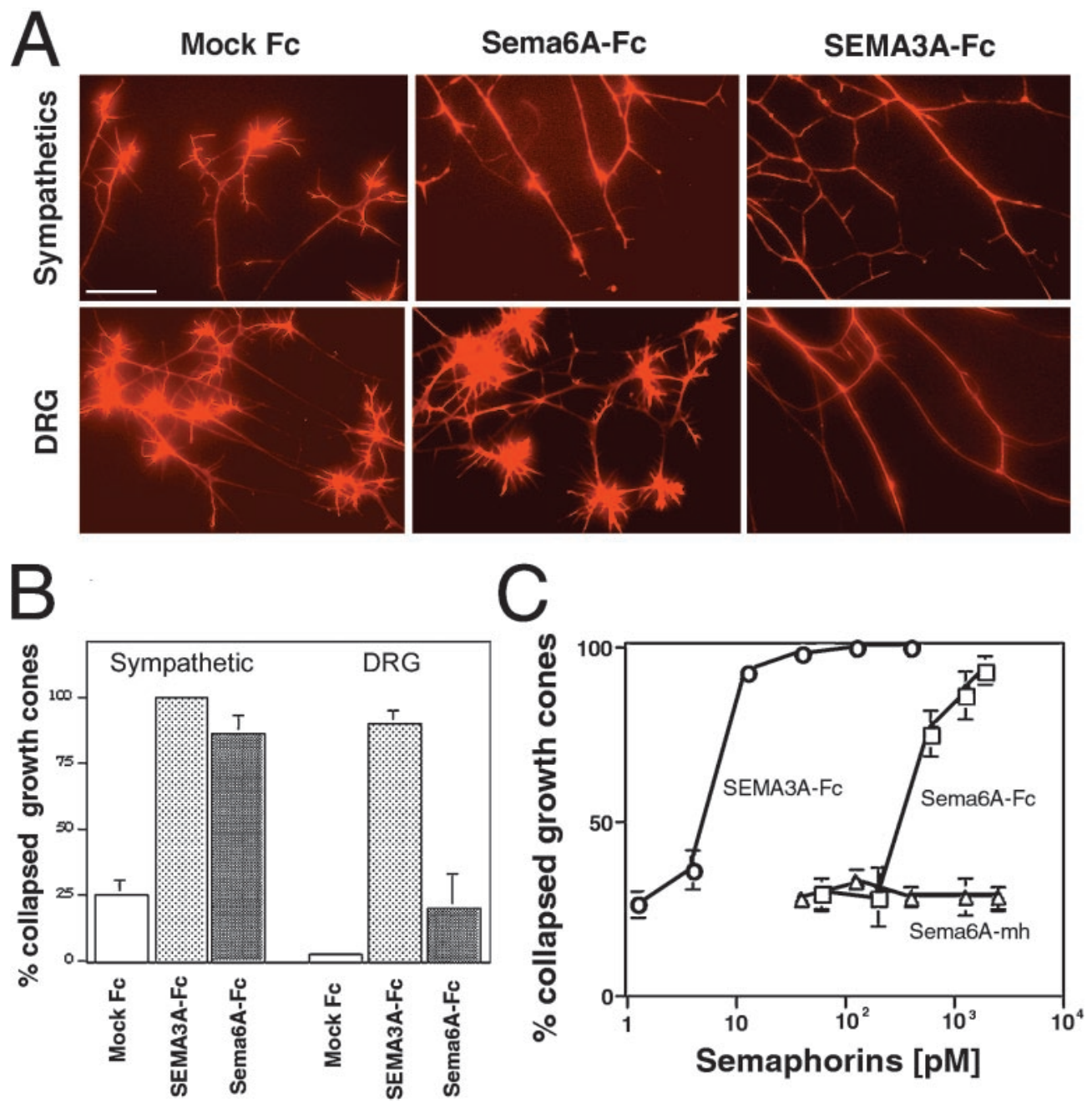

Figure 1. Sema6A collapses sympathetic but not DRG growth cones. $A$, Sema6A collapses chick sympathetic growth cones. Sympathetic ganglion derived from E8 and DRG derived from E7 chick embryos were cultured with $25 \mathrm{ng} / \mathrm{ml} \mathrm{NGF}$ on plates precoated with poly-ornithine and mouse laminin for $20 \mathrm{hr}$ and then were incubated with purified Sema6A-Fc $(\sim 0.6 \mathrm{~nm})$ and conditioned medium containing SEMA3A-Fc $(\sim 0.1 \mathrm{~nm})$ for $1 \mathrm{hr}$. Cultures were then fixed and visualized with rhodamine phalloidin. Conditioned medium containing mock Fc was used as a negative control. Scale bar, 25 $\mu \mathrm{m}$. $B$, The relative responsiveness of chick sympathetic and DRG growth cones to Sema6A-Fc, SEMA3A-Fc, and Mock $\mathrm{Fc}$ as done in $A$ was plotted as the percentage of collapsed growth cones. Sema6A-Fc $(\sim 0.6 \mathrm{nM})$ collapses chick sympathetic but not DRG growth cones. SEMA3A-Fc $(\sim 0.1 \mathrm{~nm})$ collapses both sympathetic and DRG growth cones, whereas mock Fc shows no collapsing activity. SD is included. $C$, Dose-response curve comparing the growth cone collapsing activities of purified Sema6A-Fc, Sema6A-mh, and SEMA3A. The percentage of collapsed chick sympathetic growth cones is plotted against the concentration of purified proteins displayed on a logarithmic scale with SD. The concentration of purified proteins was estimated by comparing the intensity of Coomassie Blue stain in SDS-PAGE gel using BSA as standard.

\section{RESULTS}

\section{Sema6A induces the collapse of sympathetic growth cones}

The potential chemorepulsive activity of secreted semaphorins has been identified in growth cone collapse assays (Luo et al., 1993). To determine the activity of the transmembrane protein Sema6A, we have engineered two soluble versions of Sema6A, Sema6A-mh and Sema6A-Fc, by fusing the extracellular domain of Sema6A with either a Myc-His tag or an Fc domain of human IgG1 at the $\mathrm{COOH}$ terminus, respectively. Sema6A-mh and Sema6A-Fc were highly expressed in mammalian cells, and they can be detected by either an anti-myc or an anti-Fc antibody (data not shown). Supernatants collected from HEK 293 cells transfected with these fusion constructs were used as sources for soluble fusion proteins. Sema6A-Fc supernatant collapsed sympathetic, but not dorsal root ganglion (DRG), growth cones (Fig. $1 A, B)$. In comparison, SEMA3A-Fc collapsed, in a similar manner, both sympathetic and DRG growth cones. As a control, Fc domain alone showed no appreciable amount of collapsing activity (Fig. 1A,B) (Eickholt et al., 1997).

To quantify the activity of Sema6A, Sema6A-mh and Sema6A-Fc were purified to purity $\sim 50 \%$ through affinity chromatography and tested on chick sympathetic and DRG explants in the growth cone collapse assay. The collapsing activity of Sema6A-Fc and SEMA3A is dose-dependent. Sema6A-Fc in- duces the collapse of $50 \%$ of sympathetic growth cones at a concentration $\sim 200 \mathrm{pM}$, which is $\sim 200$-fold less potent than partially purified SEMA3A produced in baculovirus (Fig. 1C).

To determine whether Sema6A-Fc is active toward sympathetics of other species and whether the activity shows any rostrocaudal polarity, we have also tested the growth cone collapse activity of Sema6A-Fc on mouse thoracic and superior cervical sympathetic ganglia. Sema6A-Fc collapses growth cones of both mouse thoracic and superior cervical sympathetic neurons (data not shown).

\section{Sema6A-Fc collapses sensory growth cones at a concentration 10-fold higher than for sympathetics}

Although Sema6A-Fc supernatants and concentrations of purified Sema6A-Fc up to $300 \mathrm{pm}$ showed no effect on DRG growth cones, higher concentrations of Sema6A-Fc collapsed DRG growth cones (Fig. 2). DRG explants cultured in either NGF or neurotrophin-3 (NT-3) were treated with doses of $0.3,1.0$, or 3.0 nM Sema6A-Fc. These two neurotrophins support the survival of the two major populations of early embryonic DRG neurons in vitro (Hory-Lee at al., 1993; Messersmith et al., 1995).

Unlike sympathetic neurons, which showed a half-maximal concentration for growth cone collapse by Sema6A-Fc at $\sim 200$ pM (Fig. $1 C$ ), DRG neurons showed no response to $300 \mathrm{pm}$ (0.3 nM) Sema6A-Fc (Fig. $2 A, B$ ). In contrast, both NGF-sensitive 
A
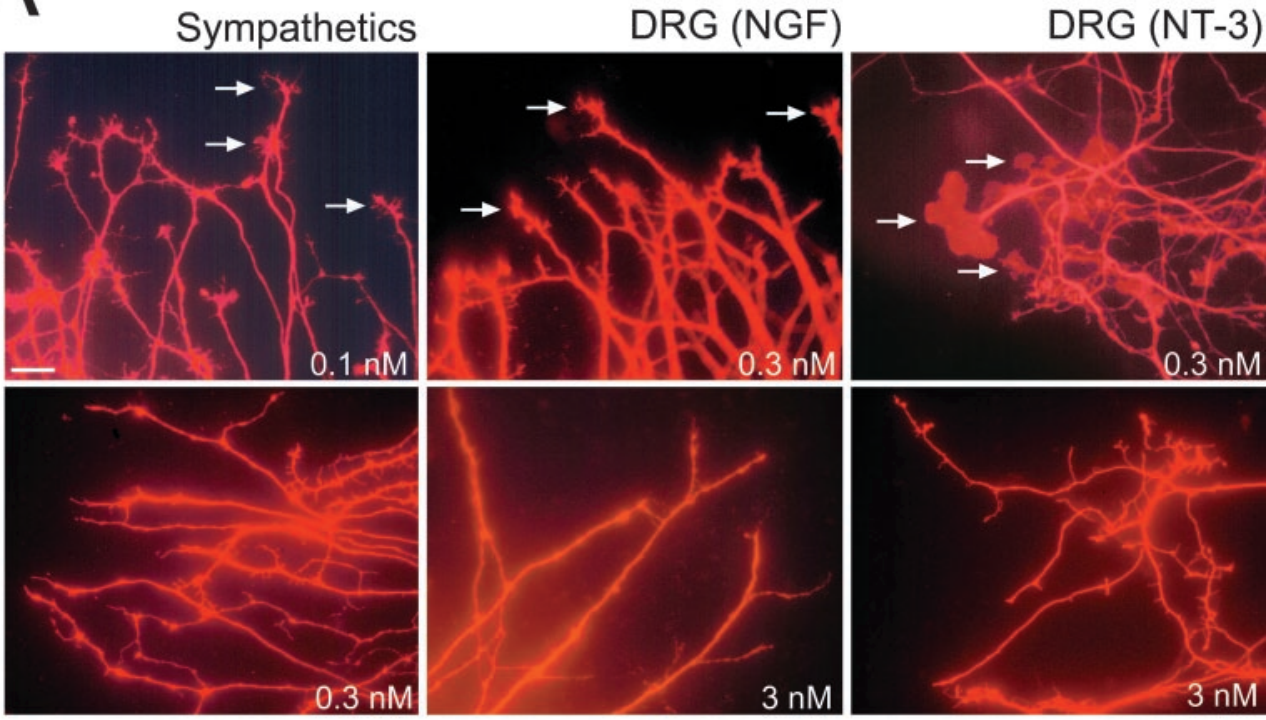

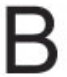

Sema6A-Fc Growth Cone Collapse

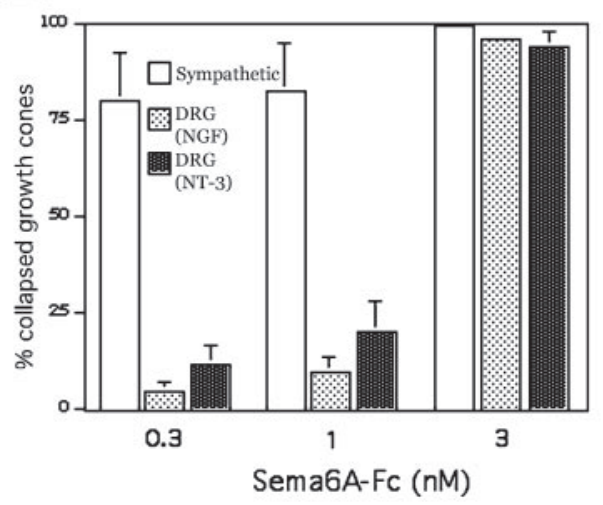

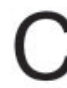

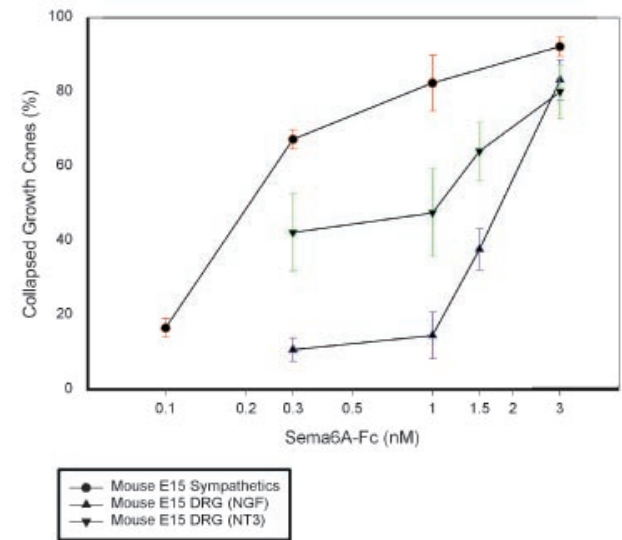

Figure 2. High concentrations of Sema6A-Fc collapse DRG, as well as sympathetic growth cones. $A$, Sema6A-Fc can collapse growth cones of two distinct DRG neuron populations, as well as sympathetics. Panels from left to right show growth cones from mouse E15 culture of sympathetic ganglia in $25 \mathrm{ng} / \mathrm{ml}$ NGF (left), dorsal root ganglia cultured in $25 \mathrm{ng} / \mathrm{ml} \mathrm{NGF} \mathrm{(center),} \mathrm{and} \mathrm{dorsal}$ root ganglia cultured in $25 \mathrm{ng} / \mathrm{ml} \mathrm{NT-3}$ (right). Axons and growth cones are specifically labeled with anti-GAP-43. Concentrations of Sema6A-Fc corresponding to each image are shown in the bottom right corner of each image. Arrows indicate examples of intact growth cones for each neuronal population. Sympathetic growth cones are collapsed by treatment with 0.3 nм Sema6A-Fc but not by treatment with $0.1 \mathrm{~nm}$ Sema6A-Fc. Treatment with $0.3 \mathrm{~nm}$ Sema6A-Fc fails to collapse growth cones of either NGF- or NT-3-sensitive DRG neurons; however, treatment with $3 \mathrm{nM}$ Sema6A-Fc collapses growth cones for both of these populations. Note that large, lamellopodialshaped growth cones indicated in the top right panel are typical of the particular NT-3-dependent murine embryonic DRG neurons. Scale bar, $25 \mu \mathrm{m}$. B, Growth cone collapse of E8 chick sympathetic and E7 DRG neurons. E8 chick sympathetic or E7 DRG explants were cultured, as were mouse ganglia in $A$ and $C$. Bars show percentage of collapsed growth cones with SD after treatment with $0.3,1$, or $3 \mathrm{~nm}$ partially purified Sema6A-Fc. Sympathetic growth cones show $\sim 80 \%$ growth cone collapse by $0.3 \mathrm{~nm}$ Sema6A-Fc, whereas comparable growth cone collapse is not observed for either sensory population below 3 nм Sema6A-Fc. $C$, Dose-response curves for mouse E15 growth cone collapse by purified Sema6A-Fc. Percent of collapsed growth cones is shown with SD for sympathetics and DRG explants

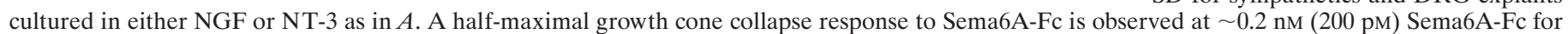

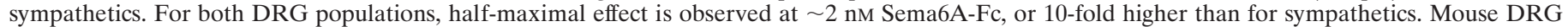

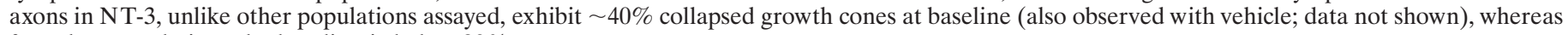
for other populations the baseline is below $20 \%$.

and NT-3-sensitive DRG neurons showed progressively greater percentages of collapsed growth cones at 1.0 and $3.0 \mathrm{~nm}$ Sema6A-Fc (Fig. 2B,C). Both populations of DRG neurons show approximately the same sensitivity to Sema6A-Fc but are $\sim 10$-fold less sensitive than sympathetic neurons; a half-maximal growth cone collapse effect is predicted at $\sim 2 \mathrm{~nm}$ Sema6A-Fc for DRG, which is exactly 10-fold higher than for sympathetics (Fig. 2C).

E7 and E10 chick DRG neurons showed differential response to Sema3A when cultured in NT-3-supplemented media (Shepherd et al., 1997). We have therefore tested the activity of Sema6A-Fc on DRG neurons from these two stages. Both E7 and E10 DRG growth cones were collapsed in response to a higher concentration of Sema6a-Fc (3 nM), whether they are grown in NGF or NT-3-supplemented media (data not shown).

\section{Sema6A collapsing activity is dimerization-dependent}

Secreted semaphorins, such as SEMA3A, are known to form homodimers and the dimerization is required for activity (Klos- termann et al., 1998; Koppel and Raper, 1998). To determine whether the activity of transmembrane protein Sema6A is dependent on protein dimerization or oligomerization, we have compared the activity of Sema6A-mh and Sema6A-Fc. When run under nonreducing conditions by SDS-PAGE gel, Sema6A-Fc migrates at a size approximately twice that when run in a reducing condition (Fig. $3 A$ ). In contrast, the size of Sema6A-mh does not change when run in either reducing or nonreducing conditions. This result suggests that Sema6A-Fc behaves like a dimer linked by disulfide bonds, whereas Sema6A-mh exists as a monomer. Whereas the dimeric Sema6A-Fc induces the collapse of sympathetic growth cones in a dose-dependent manner, the monomeric Sema6A-mh does not exhibit collapsing activity at the tested concentrations (Fig. 1C). The Myc-His-tagged Sema6A was expressed as a soluble recombinant protein like the other semaphorins, and it was purified through very mild binding and elution conditions. So it is unlikely that the lack of collapsing 


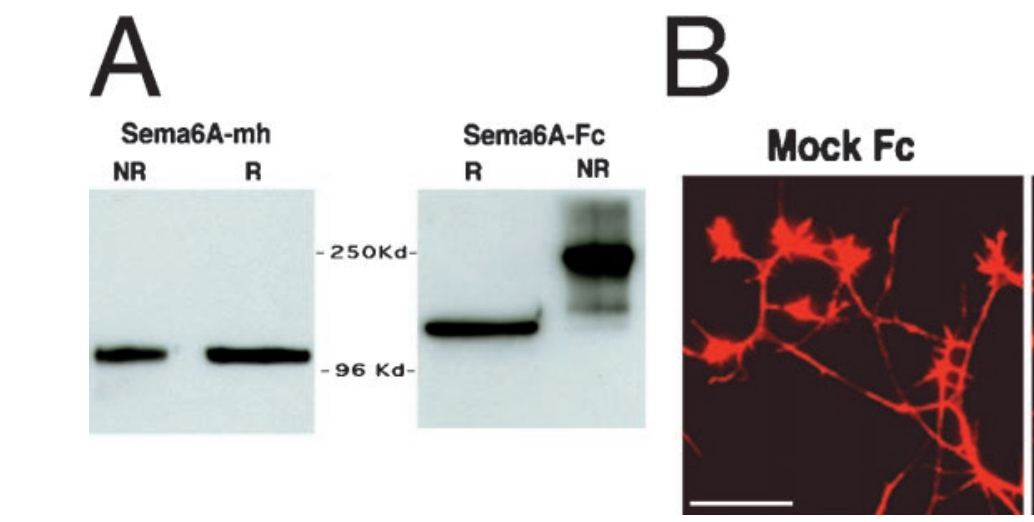

B
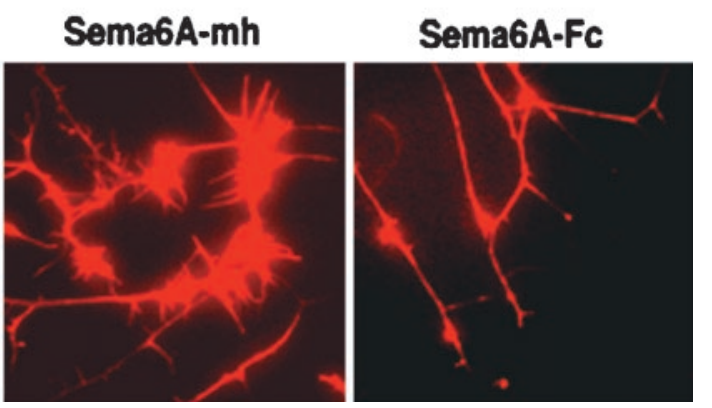

Figure 3. Sema6A collapsing activity is dimerization-dependent. $A$, Dimerization of Sema6A. Sema6A-mh and Sema6A-Fc fusion proteins were run on a 4-20\% SDS-polyacrylamide gel under both reducing $(R)$ (sample buffer with 10\% BMEM) and nonreducing conditions (NR) (sample buffer without BMEM) and visualized on Western blots with a monoclonal antibody against the Myc tag and a monoclonal antibody against the Fc tag. The expected molecular weight for Sema6A-mh monomer is $100 \mathrm{kDa}$, and Sema6A-Fc is $150 \mathrm{kDa}$. B, Dimeric Sema6A-Fc induces the collapse of chick sympathetic growth cones. Sympathetic ganglion derived from E8 chick embryos were cultured as in Figure $1 A$ and incubated with purified Sema6A-mh and Sema6A-Fc for $1 \mathrm{hr}$ before fixation and visualization with rhodamine phalloidin. Mock Fc was tested as a negative control. Scale bar, $25 \mu \mathrm{m}$.

activity of Sema6A is attributable to the denaturation occurred during protein expression and purification. Rather, Sema6A may require dimerization or oligomerization to be active. It is worth noting that a PDZ (postsynaptic density 95/discs large/zona occludens-1) protein, SEMCAP-1, was shown to induce the aggregation of transmembrane protein Sema5A (M-SemF) through its interaction with the intracellular domain of Sema5A (L.H. Wang et al., 1999). Sema6A may use a similar mechanism to regulate its activity.

\section{Sema6A repels sympathetic axons}

Because the repulsive activity of secreted semaphorins has been tested in chemorepulsion assays (Messersmith et al., 1995), we have determined the activity of Sema6A by coculturing chick E8 sympathetic or E7 DRG explants with aggregates of COS cells transfected with either Sema6A-Fc or Sema6A-mh. Sema6A-Fc secreted from COS cell aggregates dramatically reduced the amount of axon outgrowth from the proximal side of the sympathetic explants, but no effect was seen on DRG explants (Fig. $4 A, C)$. In comparison, SEMA3A-Fc had a repulsive effect on both sympathetic and DRG explants (Fig. 4A,C). No repulsive effect was observed when mock Fc (data not shown) or SEMA7A-Fc were transfected to COS cell aggregates (Xu et al., 1998). In addition, full-length transmembrane Sema6A showed no repulsive activity toward sympathetic axons in this assay when the COS cell aggregates were not in contact with the sympathetic axons.

Interestingly, Sema6A-mh also exhibited a significant amount of repulsive activity toward sympathetic axons, albeit at a much lower potency than Sema6A-Fc (Fig. 4C). It is possible that collagen matrix used in this assay may contain components that promote the dimerization or oligomerization of Sema6A-mh. Alternatively, Sema6A-mh may be active in this particular sensitive assay system.

We did not observe any effect of Sema6A-Fc on DRG axons in this system, suggesting that the COS cells could not secrete sufficient Sema6A-Fc into the collagen gel to reach a high enough concentration in the gel that would affect DRG axons. As suggested by dose-response experiments with sympathetic and DRG growth cones (Figs. $1 C, 2 B, C$ ), the maximal concentration of Sema6A-Fc in collagen gels may fall in the window between a dose affecting sympathetic axons and a dose affecting DRG axons.

In addition to the chemorepulsive effect we observed on SEMA3A-Fc, we also found that, when sympathetic explants were cocultured with SEMA3A-Fc-expressing COS cells, no sympathetic axons were grown from the majority of the sympathetic explants tested. It is not clear whether this effect is caused by the death of sympathetic neurons or by the inhibition of sympathetic axon outgrowth. Nonetheless, it suggests that SEMA3A may have as yet uncharacterized biological activity on neurons.

\section{Sema6A expression in development suggests roles in sympathetic axon guidance in vivo}

Sema6A expression was analyzed by in situ mRNA hybridization to determine whether the topographic expression of this molecule is suggestive of a role in embryonic sympathetic axon guidance. Previously published in situ hybridization data for Sema6A focused on its expression in CNS but also have shown it is expressed in the early mouse embryo and particularly in ventral neural tube, from E11 (Zhou et al., 1997). At E12, expression of Sema6A mRNA shows an expression pattern similar to that observed for Sema3A (Wright et al., 1995; Adams et al., 1996; Puschel et al., 1996). Sema6A, like Sema3A, is expressed throughout the somites and in the ventral spinal cord (Fig. 5A,B). Unlike Sema3A and spinal cord-expressed Sema3B (SemA), Sema4A (SemB), Sema3C (SemE), Sema5A (SemF), and Sema5B (SemG) (Adams et al., 1996; Puschel et al., 1996), it is also expressed in the DRG (Fig. 5, asterisks). Sema6A is likewise expressed in the gastrointestinal tract and its mesenteries (Fig. 5A,B).

At E13, Sema6A is expressed in a large assortment of developing tissues in the thoracic and abdominal regions (Fig. $5 C-F$ ). In addition to DRG and spinal cord, these include the gastrointestinal tract (Fig. $5 E, F$ ) and kidneys (Fig. 5F), and skeletal muscle throughout the embryo (Fig. 5E,F, Dia Ps).

Sema6A is not expressed in the sympathetic ganglion chains, which are visible by E12 (Fig. $5 A, B$, arrowheads) and more noticeable at E13 (Fig. 5C-F, and especially $G$, arrowheads). Notably, a ring of Sema6A-expressing tissue is observed encircling the sympathetic chains, which themselves do not express Sema6A (Fig. 5C,D,G). This particular expression pattern is observable from E12 throughout embryonic development (data 
A
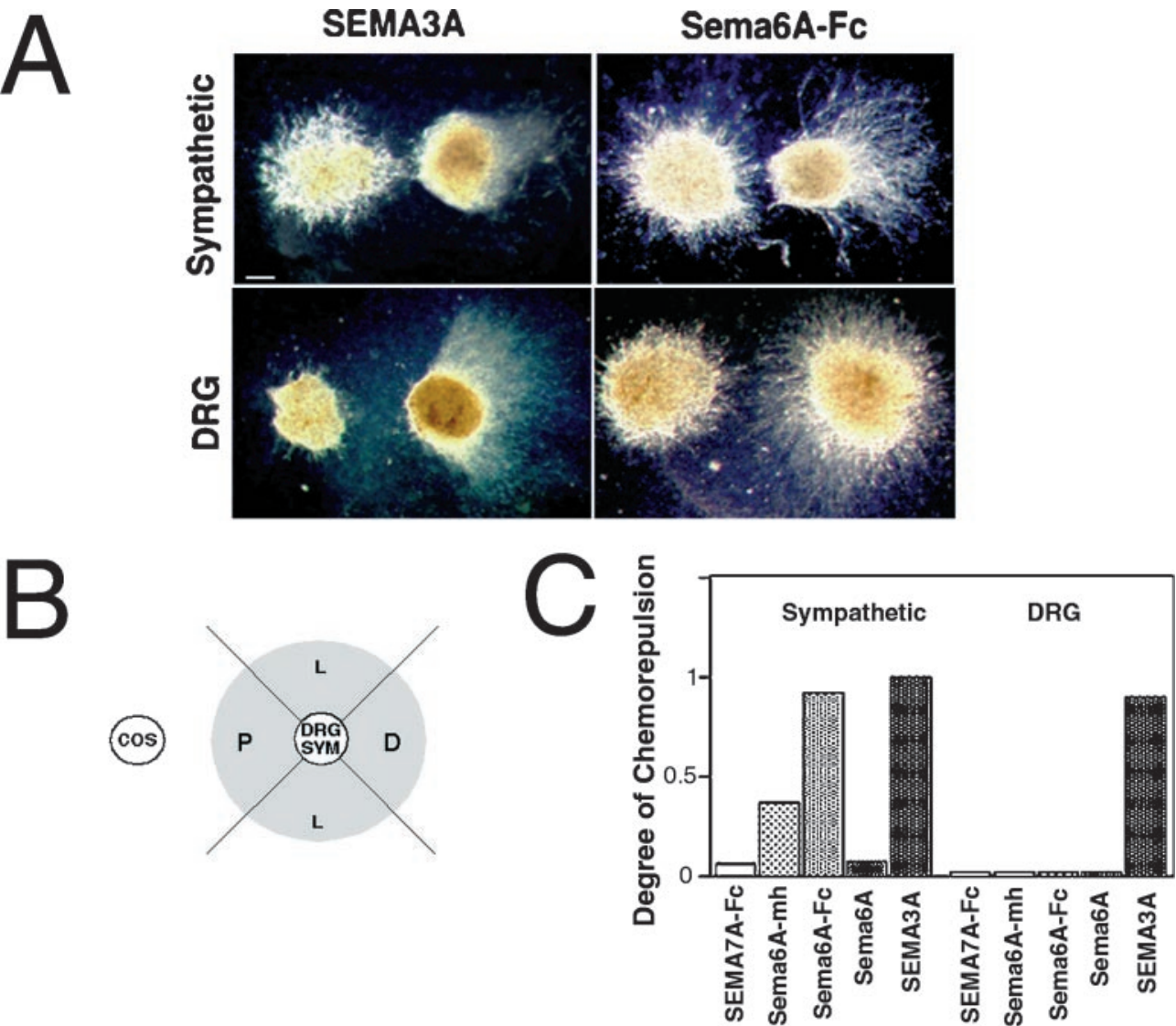

Figure 4. Sema6A repels chick sympathetic but not DRG axons. $A$, Sema6A repels chick sympathetic axons. E8 chick sympathetic and E7 chick DRG explants were cocultured for $72 \mathrm{hr}$ at a distance from aggregates of COS-7 cells (left) secreting Sema6A-Fc or SEMA3A-Fc in collagen matrix gels in medium containing $25 \mathrm{ng} / \mathrm{ml}$ NGF. Sympathetic but not DRG axons in the proximal side are repelled by aggregates of $\mathrm{COS}-7$ cells secreting Sema6A-Fc. Both sympathetic and DRG axons are repelled by aggregates of COS-7 cells secreting SEMA3A-Fc. Scale bar, $0.1 \mathrm{~mm}$. $B$, Schematic representation of the method used to quantify chemorepulsion. The field surrounding each of DRG or sympathetic explants is divided into four quadrants. The amount of neurite outgrowth in the proximal $(P)$, lateral $(L)$, and distal $(D)$ quadrants relative to the semaphorin expressing COS-7 cells was measured. Because of the strong chemorepulsive effect observed in our culture system, the repulsive activity was scored as 1 when the neurite outgrowth is present only in the distal quadrant, 0.5 when present in both lateral and distal quadrants, and 0 when present in all quadrants. The analysis was done when axonal tips were not directly in contact with COS-7 cells, therefore excluding any direct contact-mediated effects. $C$, The relative chemorepulsive activity of semaphorins was compared based on the quantitative method specified in $B$.

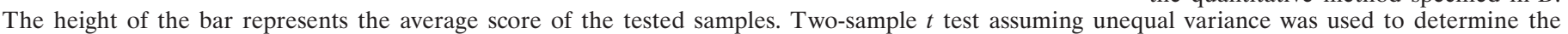

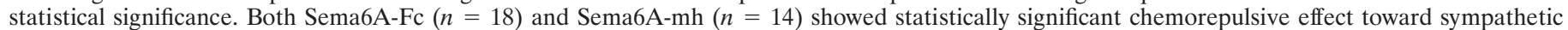
axons when compared with SEMA7A-Fc $(n=14)$, with $p<0.0001$ and $p<0.005$, respectively.

not shown for ages after E15). At these ages, when the sympathetic chains are in their early development, the expression of Sema6A around the sympathetic chain is most noticeable in the thoracic region, from the inferior cervical-first thoracic sympathetic ganglion level (Fig. 5C, arrowheads) to midthoracic ganglia (Fig. 5D,G).

Sema6A expression is absent in cervical, as well as thoracic, sympathetic ganglia (Fig. $6 A, S C G$ ). In contrast, the glossopharyngeal ganglia and cochlea (Fig. $6 B$ ), immediately superior to the superior cervical ganglia (Fig. 6A), show a high level of Sema6A mRNA labeling. Additionally, skeletal muscles in the vicinity of cervical and thoracic sympathetic ganglia (Fig. $6 A, B$ ) strongly express Sema6A. Sema6A is also expressed in the eye and optic nerve (Fig. 6C, arrowheads denote optic nerve), as well as the olfactory epithelium and other nonsympathetic cranial ganglia (data not shown). Consequentially, we hypothesize that Sema6A prevents the sympathetic innervation of nonsympathetic neural tissues in physical proximity to the peripheral nervous system.

Sema6A expression in non-neural tissues is most widespread during the early stages of embryonic development, from E12 through E15. From E15, there begins a period of substantial downregulation of Sema6A message in several tissues. From E15 to E16, there is a dramatic loss of detectable Sema6A message signal from the lung (Fig. 7A,B). Sema6A message is likewise reduced in skeletal muscle (Fig. 7, compare $B, D$ with $A, C$ ), DRG (Fig. $7 C, D$ ), and abdominal mesenteries (Fig. $7 C, D$ ), between E15 and E16. Indeed, at E16, the only evident sites of expression of Sema6A in the thorax and abdomen are the spinal cord, excluding the dorsal horn (Fig. $7 A-D$ ), and the epithelium of the small intestine (Fig. 6D,E).

\section{DISCUSSION}

\section{Sema6A, a transmembrane semaphorin, is chemorepulsive for sympathetic neurons}

Since the identification of semaphorins as a large family of potential axon guidance molecules, it has become an evident question whether these molecules function overwhelmingly as axonal chemorepellents versus occupying other roles in development. A systematic screen to identify novel activities of semaphorins on embryonic axons originally showed soluble Sema6A fusion proteins to be active growth cone collapse agents for embryonic chick sympathetic neurons, but not DRG neurons. This activity was confirmed by means of the collagen matrix chemorepulsion assay. At higher concentrations, soluble Sema6A fusion proteins were shown to collapse DRG growth cones, as well as sympathetic growth cones. Both NGF and NT-3 responsive populations responded at these higher concentrations.

These results demonstrate the principle that membrane-bound semaphorins may act as chemoinhibitory molecules in vertebrate nervous system development: a role similar to and likely overlapping with that of the class 3 semaphorins. Before this study, chemorepulsive or chemoattractive roles have been reported for several vertebrate class 3 semaphorins, but not for any of the identified vertebrate transmembrane semaphorins. While our 


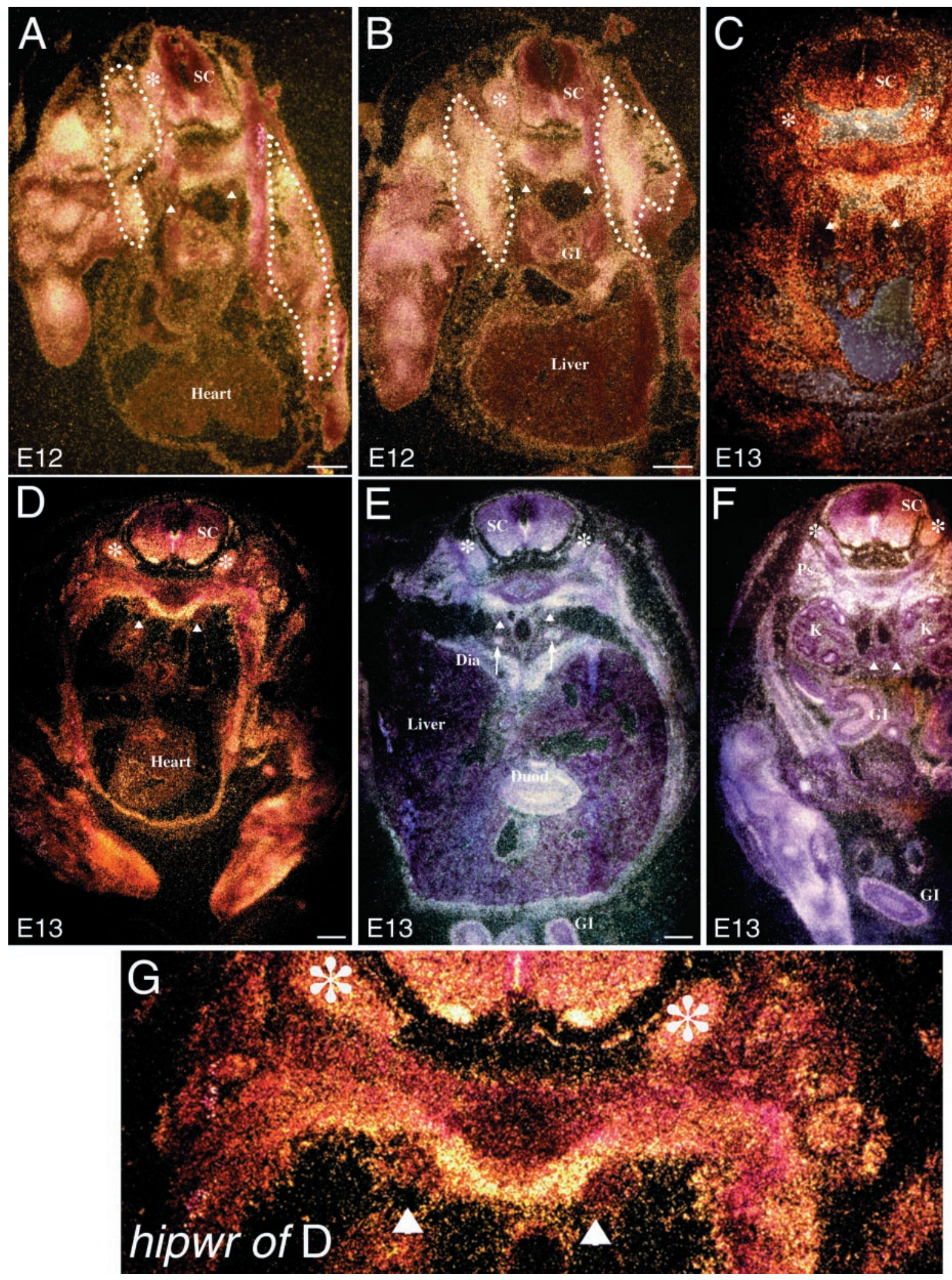

Figure 5. Expression of murine Sema6A mRNA in early development (E12-E13). Radiolabeled in situ hybridization shows sites of Sema6A mRNA expression in horizontal sections of mouse embryos at E12 $(A, B)$ and E13 $(C-G)$. Sections through E12 embryos at midthoracic $(A)$ and upper abdominal $(B)$ levels show Sema6A mRNA expression in the somites (dotted outline), limb buds, ventral portions of the spinal cord ( $S C$ ), dorsal root ganglia (asterisks), and the gastrointestinal tract and its mesenteries $(G I)$. Sema6A is not expressed in the heart or liver, as shown. At both E12 ( $A$, $B$ ) and E13 $(C-G)$, Sema6A mRNA is excluded from the sites of the sympathetic chains (small arrowheads in $A-G$ ) but is consistently expressed in dorsal root ganglia (asterisks, $A-G)$ and the ventral portions of the spinal cord $(S C, A-G)$. At E13, Sema6A expression is shown at the following levels: lower cervical $(C)$, midthoracic $(D$, including forelimb, and high power of sympathetic ganglia in $G)$, upper abdominal $(E)$, and lower abdominal $(F$, including hindlimb). Sema6A mRNA is not expressed in the heart $(D)$ or liver $(E)$. It is strongly expressed in the skeletal muscles, (Figure legend continues) 
work was being prepared for publication, another member of class 6 semaphorin, Sema6C (Sema Y), was reported to collapse someof the sensory growth cones (Kikuchi et al., 1999). This molecule is closely homologous to Sema6A, suggesting multiple class 6 semaphorins are likely to have activities similar to class 3 semaphorins.

We have observed that Sema6A is 200-fold less active than SEMA3A in the growth cone collapse assay. We do not know the reason for this sensitivity difference. One possibility is that a functionally relevant transmembrane semaphorin is not required to be as active as a secreted semaphorin because it is localized on the cell surface and therefore it may have a high effective concentration. Alternatively, the Fc-tagged soluble Sema6A is not fully active compared with the transmembrane Sema6A.

\section{The dimerization requirement for Sema6A suggests a common mechanism of semaphorin function}

Whereas the dimeric fusion protein Sema6A-Fc collapsed and repelled sympathetic growth cones, the monomeric Sema6A-mh fusion protein was not comparably active in these assays. This suggests class 6 semaphorins are active as dimers or oligomers, similar to what has been observed for class 3 semaphorins (Klostermann et al., 1998; Koppel and Raper, 1998). Despite this common feature, Sema6A does not bind to either neuropilin-1 or neuropilin-2, the identified receptor components for class 3 semaphorins (Chen et al., 1997) (X. Xu and Y. Luo, unpublished observation). Instead, receptors for Sema6A and other class 6 semaphorins are likely to be plexins, a family of molecules conserved from insects to vertebrates (Kameyama et al., 1996; Maestrini et al., 1996; Fujisawa et al., 1997; Comeau et al., 1998, Winberg et al., 1998). It has been shown that VESPR, a member of plexin family, is a receptor for a vaccinia virus semaphorin, and that Drosophila Plexin A is a functional receptor mediating the axon guidance function of Drosophila Sema-1a. A recently published study has shown that a large, multiclass family of plexins exists, with each class of plexins potentially comprising receptor components for a particular class of semaphorins (Tamagnone et al., 1999). Based on our results and those of recent studies, it appears likely that the receptors for class 6 semaphorins include a class A plexin component, as do the receptors for class 3 semaphorins (Takahashi et al., 1999; Tamagnone et al., 1999).

\section{Sema6A expression suggests an inhibitory axon guidance function on sympathetic neurons}

The case for Sema6A as a chemoinhibitory factor is clearest with respect to sympathetics. Sema6A is strikingly absent from sympathetic ganglia. Furthermore, developing sympathetic axons must avoid tissues such as skeletal muscle, sensory ganglia, and optic nerve, which express Sema6A. We have also observed that Sema6A is expressed in a ringing pattern in the surrounding sheath of the sympathetic chain (as in Fig. $5 G$ ), suggesting a role for Sema6A in restricting the longitudinal course of axons forming the sympathetic chains, preventing them from extending projections outside the chains except at the specific exit points of the white rami communicantes. Sema6A is not expressed in the sympathetic chains themselves or in sympathetic target tissues, such as the heart and blood vessels.
Repulsion of embryonic chick sympathetic axons from membrane fractions derived from lung and skeletal muscle, tissues that express Sema6A, has been observed previously in a stripe assay (Kuromi, 1992). In earlier studies, DRG and sympathetic axons were shown to avoid retinal axons when DRG or sympathetic explants are cocultured with retinal explants (Bray et al., 1980; Kapfhammer and Raper, 1987b). In fact, growth cone collapse was first observed in the encounter of sympathetic growth cones with retinal axons (Kapfhammer and Raper, 1987a). It has been suggested that retinal axons contain a central label that can induce the collapse of sympathetic growth cones. Yet the molecular identity of such a signal has not been identified. The activity and expression profiles of Sema6A fit the trait of this long sought guidance signal.

It is also notable that Sema6A is expressed in the embryonic lung and gastrointestinal tract. The lung and gastrointestinal tract contain their own neuronal plexi, which are distinct from the parasympathetic and sympathetic systems. These tissues are not innervated by sympathetic axons while they express Sema6A. Sema6A expression in these tissues, however, is downregulated from E15 to E16, but this downregulation is not immediately followed by sympathetic axon penetration. Sympathetic axons are absent from the lungs throughout embryonic development, their extrinsic innervation in utero being predominantly parasympathetic (Sparrow and Weichselbaum, 1997). Likewise, extrinsic sympathetic innervation of the myenteric and submucosal plexi of the bowel was observed to develop in the early postnatal period in rats (Hill and $\mathrm{Ngu}, 1987$ ). It is likely that, after the rapid downregulation of Sema6A message in lung, skeletal muscle, and mesenteries occurring at E15-E16, the inhibitory role continues to be occupied by some other molecule(s). This appears particularly likely because the soluble semaphorin Sema3F (formerly named Sema IV), which, like Sema6A, can repel sympathetic axons, is expressed in both the lung and the gastrointestinal tract after Sema6A expression has been downregulated in these viscera (Giger et al., 1998).

\section{Sema6A activity on sensory versus sympathetic neurons may correspond to distinct roles in vivo}

More perplexing is the issue that Sema6A is expressed in both dorsal root ganglia and tissues such as muscle and dermis, which they innervate. Because Sema6A was observed to collapse the growth cones of dorsal root ganglion axons, albeit at a 10 -fold higher concentration than that affecting sympathetics, it is more difficult to conclude whether Sema6A acts as a chemorepellent for DRG axons in vivo. The expression pattern of Sema6A overlaps with that of Sema3A, which repels both sensory and sympathetic neurons, in sites such as early somites, skeletal muscles, and ventral spinal cord. A weak sensitivity of DRG neurons to Sema6A may help explain why, in Sema3A null mice, although invasion of these areas by sensory neurons is observed, it is not total, and a sizable proportion of the sensory populations appear to maintain the wild-type trajectory (Taniguchi et al., 1997). Nonetheless, the presence of Sema6A in both dorsal root ganglia and target tissues suggests a different role from that for sympathetics.

\section{$\longleftarrow$}

including diaphragm $(E, D i a)$ and psoas $(F, P s)$. It is also expressed in the gastrointestinal tract, including duodenum $(E, D u o d)$, stomach $(F$, Sto $)$, and intestinal loops including herniations present at this age $(G I$ in $E, F)$. Expression is also observed in the inferior poles of the lungs $(E$, arrows) and the kidneys $(K$ in $F)$. $G$ is a high-power view of $D$ showing Sema6A mRNA excluded from the sympathetic ganglia but present in the surrounding sheath (arrowheads) and in dorsal root ganglia (asterisks). Scale bars, $0.5 \mathrm{~mm}$. 

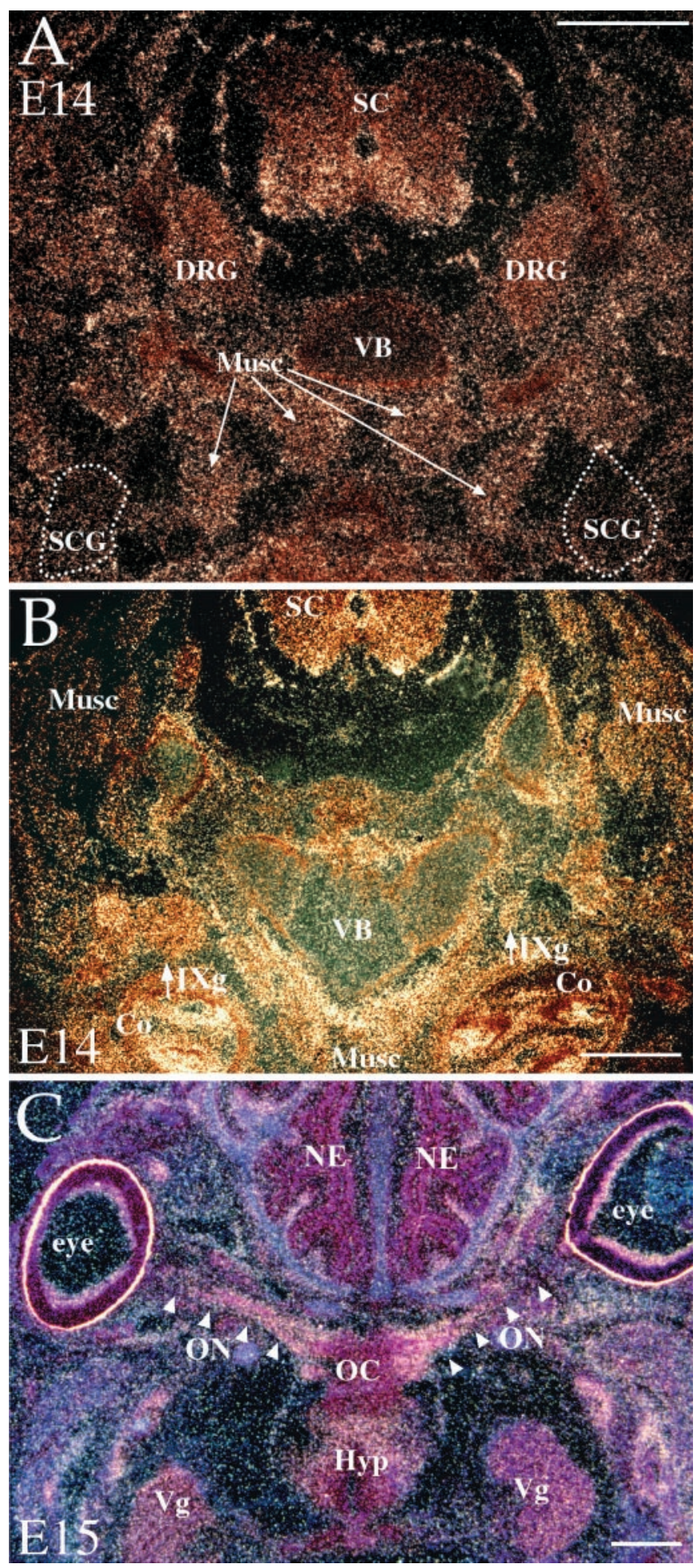

Figure 6. Expression of Sema6A mRNA in cranial tissues avoided by sympathetic axons. $A$, Sema6A expression at E14 at the level of the superior cervical ganglia $(S C G)$. Sema6A is not expressed in superior cervical ganglia (also surrounded by dotted outline). Sema6A is expressed, however, in the adjacent skeletal muscles (Musc, long arrows), as well as dorsal root ganglia $(D R G)$ and cervical spinal cord $(S C)$. VB denotes the vertebral body. $B$, Sema6A expression at the level of the glossopharyngeal ganglia, directly superior to the superior cervical ganglia. Sema6A is strongly expressed in the glossopharyngeal ganglia (short arrows, $I \mathrm{Xg}$ ) and cochlea $(\mathrm{Co})$, as well as skeletal muscles (Musc). C, Sema6A expression at $\mathrm{E} 15$ at the level of the optic chiasm. Sema6A is expressed in the trigeminal ganglia $(V g)$, eyes (specifically retinal ganglion cell layer; the intense
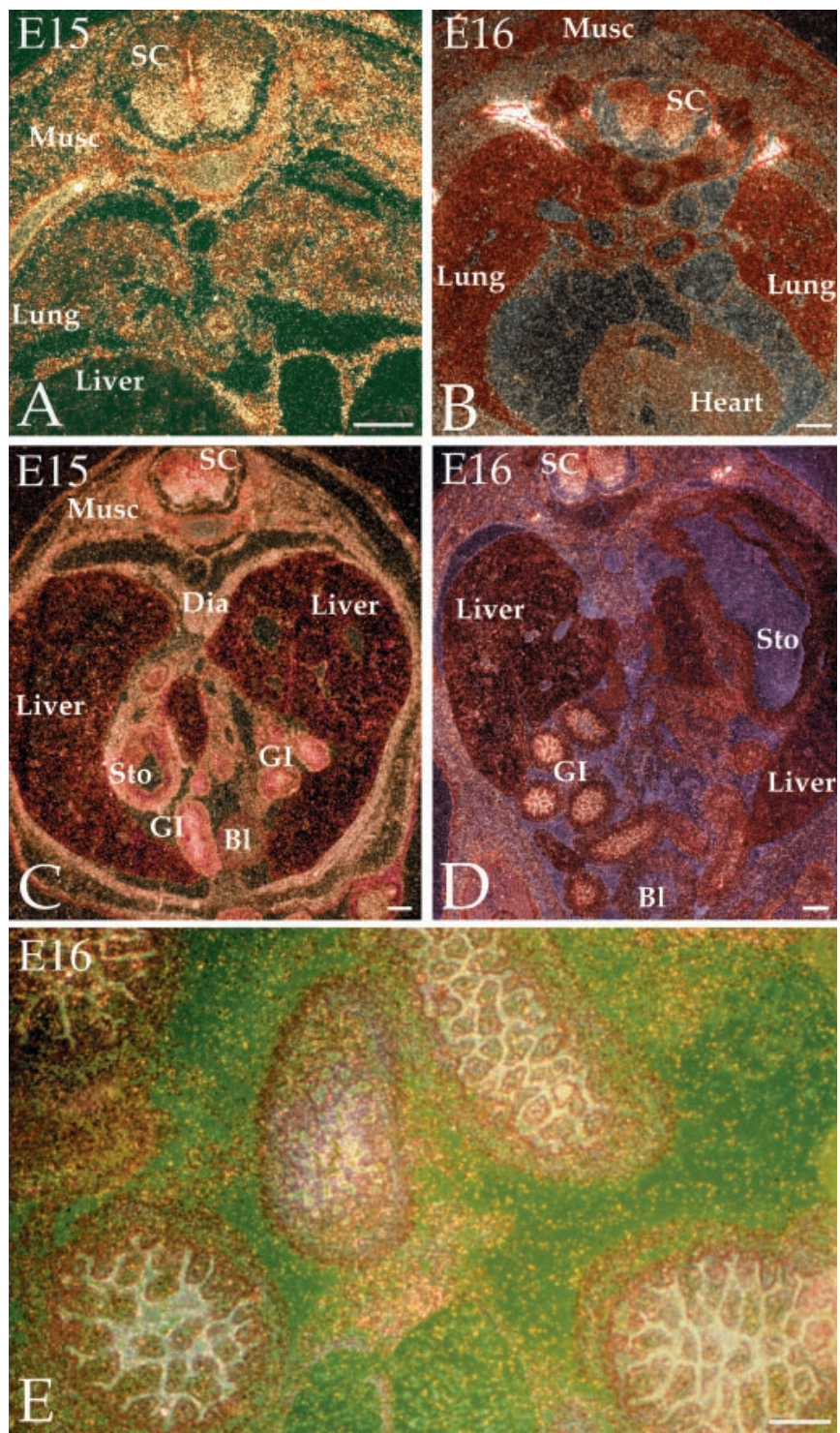

Figure 7. Visceral Sema6A expression altered from E15 to E16. Expression of Sema6A mRNA is shown at E15 $(A, C)$ and E16 $(B, D, E)$. Sema6A is highly expressed in the lung and in thoracic skeletal muscle at $\mathrm{E} 15(A)$ but is downregulated in these tissues by E16 $(B)$. In contrast, Sema6A expression in the spinal cord $(S C)$ remains high. At E15, Sema6A is also expressed in multiple abdominal locations $(C)$, including the stomach (Sto) and intestines $(\mathrm{GI})$, but not the bladder $(\mathrm{Bl})$. It is also highly expressed in skeletal muscle (Musc), including diaphragm (Dia). At E16 $(D)$, in contrast, Sema6A mRNA is no longer observed in the wall of the stomach (Sto) or in mesenteries of the gastrointestinal tract. It is still expressed at a high level in spinal cord $(S C)$ but appears downregulated in muscle. A high-power view of the intestine at E16 $(E)$ shows that the high level of signal in the intestine at this age is confined to the epithelium. Scale bars: $A-D, 0.5 \mathrm{~mm} ; E, 0.1 \mathrm{~mm}$.

Several plexins are also expressed by DRG neurons, as well as by sympathetics (Takahashi et al., 1999; Tamagnone et al., 1999), but whether receptor differences can explain the differences in sensitivity is unclear. Sema6A in sensory ganglia may serve a

\section{$\leftarrow$}

labeling of the sclera may be artifactual), and optic nerves (arrowheads, $O N)$. Although it is not expressed in the optic chiasm, it is expressed in the hypothalamus (Hyp). It is also excluded from the nasal epithelium $(N E)$. E14-E15, Horizontal sections. Scale bars, $0.5 \mathrm{~mm}$. 
function other than chemorepulsion, such as an inhibition of axon branching within the sensory ganglia themselves. Notably, dual functions on axon guidance and branching on distinct neuronal populations have been observed for the slit family molecule Slit2 (Ba-Charvet et al., 1999; Brose et al., 1999; Li et al., 1999; K.H. Wang et al., 1999) (for review, see Zinn and Sun, 1999). Alternatively, Sema6A could be a chemorepellent for both classes of axons in vivo. The example is not without precedent: motor neurons can be repelled by Sema3A, which is expressed in the ventral spinal cord (Varela-Echavarria et al., 1997).

\section{Multiple molecules are likely to direct guidance of PNS axons}

In our initial description of the cloning and expression of Sema6A, we hypothesized that multiple semaphorins would contribute to a complex addressing system directing particular axons to their targets by means of selective chemorepulsion or growth restriction (Zhou et al., 1997). The activity we have now observed for Sema6A on sympathetic axons, and Sema6A expression in tissues that must be avoided by these axons in development, are findings consistent with this hypothesis.

Several of the class 3 semaphorins, including SEMA3A, have also been shown to be repulsive for sympathetic axons (Chen et al., 1998; Giger et al., 1998; Klostermann et al., 1998). Mice lacking expression of Sema3A or neuropilin-1 do not have significant abnormalities of sympathetic chain structure (Kitsukawa et al., 1997; Taniguchi et al., 1997). In retrospect, this is consistent with the activity of Sema6A and localization around the sympathetic chains. Additionally, many of the sites of Sema6A expression in development are also sites of expression of other semaphorins and of other nonsemaphorin axon inhibitors, such as slit (Brose et al., 1999; Li et al., 1999; K.H. Wang et al., 1999). Among the class 3 semaphorins that have been shown previously to repel sympathetic axons, several are expressed at sites at which they could complement with Sema6A in preventing sympathetic axon ingrowth. As examples, Sema3A is expressed in the sheath of the optic nerve (Zhou et al., 1997), and Sema3F shows expression similar to or overlapping with that of Sema6A in kidney, lung, and the gastrointestinal tract (Giger et al., 1998). So it is likely that many of these overlapping molecules have redundant functions acting on any one class of axons, but that precise combinations of them may guide many classes of axons, by process of elimination, to their target tissues.

\section{REFERENCES}

Adams RH, Betz H, Puschel AW (1996) A novel class of murine semaphorins with homology to thrombospondin is differentially expressed in early embryos. Mech Dev 57:33-45.

Adams RH, Lohrum M, Klostermann A, Betz H, Puschel AW (1997) The chemorepulsive activity of secreted semaphorins is regulated by furin-dependent proteolytic processing. EMBO J 16:6077-6086.

Ba-Charvet KTN, Brose K, Marillat V, Kidd T, Goodman CS, TessierLavigne M, Sotelo C, Chedotal A (1999) Slit2-mediated chemorepulsion and collapse of developing forebrain axons. Neuron 22:463-473.

Behar O, Golden JA, Mashimo H, Schoen FJ, Fishman MC (1996) Semaphorin III is needed for normal patterning and growth of nerves, bones, and heart. Nature 383:525-528.

Bork P, Doerks T, Springer TA, Snel B (1999) Domains in plexins: links to integrins and transcription factors. Trends Biol Sci 24:261-263.

Bray D, Wood P, Bunge RP (1980) Selective fasciculation of nerve fibers in culture. Exp Cell Res 130:241-250.

Brose K, Bland KS, Wang KH, Arnott D, Henzel W, Goodman CS, Tessier-Lavigne M, Kidd T (1999) Slit proteins bind robo receptors and have an evolutionarily conserved role in repulsive axon guidance. Cell 96:795-806.

Chen H, Chedotal A, He Z, Goodman CS, Tessier-Lavigne M (1997)
Neuropilin-2, a novel receptor of the neuropilin family, is a high affinity receptor for the semaphorins Sema E and Sema IV but not Sema III. Neuron 19:547-559.

Chen H, He Z, Bagri A, Tessier-Lavigne M (1998) Semaphorinneuropilin interactions underlying sympathetic axon responses to class III semaphorins. Neuron 21:1283-1290.

Comeau MR, Johnson R, DuBose RF, Petersen M, Gearing P, VandenBos T, Park L, Farrah T, Buller RM, Cohen JI, Strockbine LD, Rauch C, Spriggs MK (1998) A poxvirus-encoded semaphorin induces cytokine production from monocytes and binds to a novel cellular semaphorin receptor, VESPR. Immunity 8:473-482.

Eckhardt F, Behar O, Calautti E, Yonezawa K, Nishimoto I, Fishman MC (1997) A novel transmembrane semaphorin can bind c-src. Mol Cell Neurosci 9:409-419.

Eickholt BJ, Morrow R, Walsh FS, Doherty P (1997) Structural features of collapsin required for biological activity and distribution of binding sites in the developing chick. Mol Cell Neurosci 9:358-371.

Feiner L, Koppel AM, Kobayashi H, Raper JA (1997) Secreted chick semaphorins bind recombinant neuropilin with similar affinities but bind different subsets of neurons in situ. Neuron 19:539-545.

Fujisawa H, Ohta K, Kameyama T, Murakami Y (1997) Function of a cell adhesion molecule, plexin, in neuron network formation. Dev Neurosci 19:101-105.

Giger RJ, Urquhart ER, Gillespie SKH, Levengood DV, Ginty DD, Kolodkin AL (1998) Neuropilin-2 is a receptor for semaphorin IV: insight into the structural basis of receptor function and specificity. Neuron 21:1079-1092.

He Z, Tessier-Lavigne M (1997) Neuropilin is a receptor for the axonal chemorepellent Semaphorin III. Cell 90:739-751.

Hill CE, Ngu MC (1987) Development of the extrinsic sympathetic innervation to the enteric neurones of the rat small intestine. J Auton Nerv Syst 19:85-93.

Hory-Lee F, Russell M, Lindsay RM, Frank E (1993) Neurotrophin 3 supports the survival of developing muscle sensory neurons in culture. Proc Natl Acad Sci USA 90:2613-2617.

Kameyama T, Murakami Y, Suto F, Kawakami A, Takagi S, Hirata T, Fujisawa H (1996) Identification of plexin family molecules in mice. Biochem Biophys Res Commun 226:396-402.

Kapfhammer JP, Raper JA (1987a) Collapse of growth cone structure on contact with specific neurites in culture. J Neurosci 7:201-212.

Kapfhammer JP, Raper JA (1987b) Interaction between growth cones and neurites growing from different neural tissues in culture. J Neurosci 7:1595-1600.

Kikuchi K, Ishida H, Kimura T (1997) Molecular cloning of a novel member of semaphorin family genes, semaphorin Z. Brain Res Mol Brain Res 51:229-237.

Kikuchi K, Chedotal A, Hanafusa H, Ujimasa Y, de Castro F, Goodman CS, Kimura T (1999) Cloning and characterization of a novel class VI semaphorin, Semaphorin Y. Mol Cell Neurosci 13:9-23.

Kitsukawa T, Shimizu M, Sanbo M, Hirata T, Taniguchi M, Bekku Y, Yagi T, Fujisawa H (1997) Neuropilin-semaphorin III/D-mediated chemorepulsive signals play a crucial role in peripheral nerve projection in mice. Neuron 19:995-1005.

Klostermann A, Lohrum M, Adams RH, Puschel AW (1998) The chemorepulsive activity of the axonal guidance signal semaphorin D requires dimerization. J Biol Chem 273:7326-7331.

Kobayashi H, Koppel AM, Luo Y, Raper JA (1997) A role for collapsin-1 in olfactory and cranial sensory axon guidance. J Neurosci 17:8339-8352.

Kolodkin AL, Matthes DJ, O'Connor TP, Patel NH, Admon A, Bentley D, Goodman CS (1992) Fasciclin IV: sequence, expression, and function during growth cone guidance in the grasshopper embryo. Neuron 9:831-845.

Kolodkin AL, Matthes DJ, Goodman CS (1993) The semaphorin genes encode a family of transmembrane and secreted guidance molecules. Cell 75:1389-1399.

Kolodkin AL, Levengood DV, Rowe EG, Tai YT, Giger RJ, Ginty DD (1998) Neuropilin is a semaphorin receptor. Cell 90:753-762.

Koppel AM, Raper JA (1998) Collapsin-1 covalently dimerizes, and dimerization is necessary for collapsing activity. J Biol Chem 273:15708-15713.

Koppel AM, Feiner L, Kobayashi H, Raper JA (1997) A 70 amino acid region within the semaphorin domain activates specific cellular response of semaphorin family members. Neuron 19:531-537. 
Kuromi H (1992) Characterization of substances which promote or repel sympathetic fiber growth in vitro. Neurosci Res 14:213-225.

Li, H-S, Chen J-H, Wu W, Fagaly T, Zhou L, Yuan W, Dupuis S, Jiang Z-H, Nash W, Gick C, Ornitz DM, Wu JY, Rao Y (1999) Vertebrate slit, a secreted ligand for the transmembrane protein roundabout, is a repellent for olfactory bulb axons. Cell 96:807-818.

Luo Y, Raible DE, Raper JA (1993) Collapsin: a protein in brain that induces collapse and paralysis of neuronal growth cones. Cell 75:217-227.

Luo Y, Shepherd I, Li J, Renzi MJ, Chang S, Raper JA (1995) A family of molecules related to collapsin in the embryonic chick nervous system. Neuron 14:1131-1140.

Maestrini E, Tamagnone, L, Longati P, Cremona O, Gulisano M, Bione S, Tamanini F, Neel BG, Toniolo D, Comoglio PM (1996) A family of transmembrane proteins with homology to the MET-hepatocyte growth factor receptor. Proc Natl Acad Sci USA 93:674-678.

Mark MD, Lohrum M, Puschel AW (1997) Patterning neuronal connections by chemorepulsion: the semaphorins. Cell Tissue Res 290:299-306.

Messersmith EK, Leonardo ED, Shatz CJ, Tessier-Lavigne M, Goodman CS, Kolodkin AL (1995) Semaphorin III can function as a selective chemorepellent to pattern sensory projections in the spinal cord. Neuron 14:949-959.

Puschel AW, Adams RH, Betz H (1995) Murine semaphorin D/collapsin is a member of a diverse gene family and creates domains inhibitory for axonal extension. Neuron 14:941-948.

Puschel AW, Adams RH, Betz H (1996) The sensory innervation of the mouse spinal cord may be patterned by differential expression and of differential responsiveness to semaphorins. Mol Cell Neurosci 7:419-431.

Semaphorin Nomenclature Committee (1999) Unified nomenclature for the semaphorins/collapsins. Cell 97:551-552.

Shepherd IT, Luo Y, Lefcort F, Reichardt LF, Raper JA (1997) A sensory axon repellent secreted from ventral spinal cord explants is neutralized by antibodies raised against collapsin-1. Development 124:1377-1385.

Sparrow MP, Weichselbaum M (1997) Structure and function of the adventitial and mucosal nerve plexuses of the bronchial tree in the developing lung. Clin Exp Pharmacol Physiol 24:261-268.

Takahashi T, Nakamura F, Jin Z, Kalb RG, Strittmatter SM (1998) Semaphorins A and E act as antagonists of neuropilin-1 and agonists of neuropilin-2 receptors. Nat Neurosci 1:487-493.

Takahashi T, Fournier A, Nakamura F, Wang L-H, Murakami Y, Kalb RG, Fujisawa H, Strittmatter SM (1999) Plexin-Neuropilin-1 complexes form functional Semaphorin-3A receptors. Cell 99:59-69.

Tamagnone L, Artigiani S, Chen H, He Z, Ming G-L, Song, H-J, Che- dotal A, Winberg ML, Goodman CS, Poo M-M, Tessier-Lavigne M, Comoglio PM (1999) Plexins are a large family of receptors for transmembrane, secreted, and GPI-anchored semaphorins in vertebrates. Cell 99:71-80.

Taniguchi M, Yuasa S, Fujisawa H, Naruse I, Saga S, Mishina M, Yagi T (1997) Disruption of semaphorin III/D gene causes severe abnormality in peripheral nerve projection. Neuron 19:519-530.

Tessier-Lavigne M, Goodman CS (1996) The molecular biology of axon guidance. Science 247:1123-1133.

Varela-Echavarria A, Tucker A, Puschel AW, Guthrie S (1997) Motor axon subpopulations respond differentially to the chemorepellents netrin-1 and semaphorin D. Neuron 18:193-207.

Wang KH, Brose K, Arnott D, Kidd T, Goodman CS, Henzel W, Tessier-Lavigne M (1999) Biochemical purification of a mammalian slit protein as a positive regulator of sensory axon elongation and branching. Cell 96:771-784.

Wang LH, Kalb RG, Strittmatter SM (1999) A PDZ protein regulates the distribution of the transmembrane semaphorin M-semF. J Biol Chem 274:14137-14146.

Winberg ML, Noordermeer JN, Tamagnone L, Comoglio PM, Spriggs MK, Tessier-Lavigne M, Goodman CS (1998) Plexin A is a neuronal semaphorin receptor that controls axon guidance. Cell 95:903-906.

Wong JT, Wu WT, O'Connor TP (1997) Transmembrane grasshopper Semaphorin I promotes axon outgrowth in vivo. Development 124: 3597-3607.

Wright DE, White FA, Gerfen RW, Silos-Santiago I, Snider WD (1995) The guidance molecule semaphorin III is expressed in regions of spinal cord and periphery avoided by growing sensory axons. J Comp Neurol 361:321-333.

Xu X, Ng S, Wu ZL, Nguyen D, Homburger S, Seidel-Dugan C, Ebens A, Luo Y (1998) Human semaphorin K1 is glycosylphosphatidylinisitollinked and defines a new subfamily of viral-related semaphorins. J Biol Chem 273:22428-22434.

Yu HH, Kolodkin AL (1999) Semaphorin signaling: a little less perplexin. Neuron 22:11-14.

Yu HH, Araj HH, Ralls SA, Kolodkin AL (1998) The transmembrane semaphorin Sema I is required in Drosophila for embryonic motor and CNS axon guidance. Neuron 20:207-220.

Zhou L, White FA, Lentz SI, Wright DE, Fisher DA, Snider WD (1997) Cloning and expression of a novel murine semaphorin with structural similarity to insect semaphorin I. Mol Cell Neurosci 9:26-41.

Zinn K, Sun Q (1999) Slit branches out: a secreted protein mediates both attractive and repulsive axon guidance. Cell 97:1-4. 